\title{
Hybrids of Solanum corymbiflorum and S. diploconos (Solanaceae) - a hope for new commercial varieties of edible fruits
}

\author{
Híbridos de Solanum Corymbiflorum e S. diploconos (Solanaceae) - uma alternativa para novas \\ cultivares comerciais de frutas comestíveis
}

\author{
Wojciech Maksymilian Szymański ${ }^{1}$ (ORCIC 0000-0002-1018-526X), Iwona Ziółkowska² (ORCID 0000-0001-5566-4427) \\ 1Odkrywcy Natury, 28-400 Pińczów, Poland. Webpage: https://odkrywcynatury.pl/. *Correspondence Author: scirpidiella@gmail.com \\ ${ }^{2}$ Holly-cross Mountains and Nida River Landscape Parks Complex, 25-655 Kielce, Poland.
}

Submission: 19/11/2021 / Acceptance: 09/12/2021

\begin{abstract}
Solanum diploconos (Mart.) Bohs (,guava tamarillo") and Solanum corymbiflorum (Sendtn.) Bohs („hardy tamarillo") are wild relatives to subtropical, orchard, small tree - Solanum betaceum Cav. (called simply „tamarillo"). Both these species create edible fruits, but they have not been cultivated widely so far as fruit trees. However, each one of these species has valuable features. Solanum corymbiflorum is quite hardy to frost, deciduous and early blooming both in fenological year time as well as in its lifespan but has untasty fruits. Solanum diploconos has quite good tasting fruits and it is pest and disease resistant. This work has been an attempt to connect their best features in hybrids to create new, potentially commercial cultivars to grow as fruit plants. Three types of hybrids were created: F1 hybrid type - Solanum corymbiflorum $\times$ Solanum diploconos, BC1 backrossing type - (Solanum corymbiflorum $\times$ Solanum diploconos) $\times$ Solanum corymbiflorum and the second BC1 backcrossing type - (Solanum corymbiflorum $\times$ Solanum diploconos) $\times$ Solanum diploconos. Out of the numerous variable individuals within each type, we selected three very valuable from an agronomic point of view cultivars (Solanum 'Lynn', 'Pinczow Springs' and 'Iwona'). The work with crossing and selecting the next cultivars will be continued.
\end{abstract}

KEYWORDS: Solanum corymbiflorum, Solanum diploconos, hybridisation, cultivation, new fruit cultivars.

\begin{abstract}
RESUMO
Solanum diploconos (Mart.) Bohs ("guava tamarillo") e Solanum corymbiflorum (Sendtn.) Bohs ("hardy tamarillo") são espécies silvestres de forma arbustiva - Solanum betaceum Cav. (chamado simplesmente "tamarillo"). Ambas as espécies geram frutos comestíveis, mas não têm sido cultivadas como árvores frutíferas. Entretanto, cada uma destas espécies tem características valiosas. Solanum corymbiflorum é bastante resistente à geada, perde suas folhas periodicamente e possui floração precoce, tanto no ano fenológico como em sua vida útil, mas tem frutos pouco saborosos. No entanto, Solanum diploconos tem frutos bastante saborosos e é resistente a pragas e doenças. Este estudo foi uma tentativa de captar as melhores características existentes em híbridos para criar novas cultivares, potencialmente comerciais, e que possam desenvolver como planta frutífera. Três tipos de híbridos foram criados: tipo híbrido F1 (Solanum corymbiflorum $\times$ Solanum diploconos), tipo BC1 retrocruzamento - (Solanum corymbiflorum $\times$ Solanum diploconos) $\times$ Solanum corymbiflorum e o segundo tipo BC1 retrocruzamento - (Solanum corymbiflorum $\times$ Solanum diploconos) $\times$ Solanum diploconos. Dos numerosos indivíduos variáveis dentro de cada tipo, foram selecionados três cultivares muito valiosas do ponto de vista agronômico (Solanum 'Lynn', 'Pinczow Springs' e 'Iwona'). O trabalho de cruzamento e seleção das próximas cultivares terá continuidade e aprimoramento.
\end{abstract}

PALAVRAS-CHAVE: Solanum corymbiflorum, Solanum diploconos, hibridização, cultivo, novas variedades de frutas.

The technical report present the description of new cultivars of the genus Solanum that could potentially be edible fruit plants. They were obtained by crossing of wild cousins of well-known, subtropical, important orchard tree - "tamarillo" - Solanum betaceum Cav. (HUME \& WINTERS 1949, PRINGLE \& MURRAY 1991b, BOHS 1994, PROHENS \& NUEZ 2001, WAN \& ZHUB 2020, CHEN et al. 2021a, CHEN et al. 2021b, REYES-GARCíA et al. 2021, FERNANDINO et al. 2021). S. betaceum and related taxa belong to 
section Pachyphylla of the genus Solanum, but formerly were included to genus Cyphomandra (BOHS 1995). Solanum sect. Pachyphylla covers about 35 species distributed between Mexico and South America (BOHS 1994). Two species: "Guava Tamarillo" (S. diploconos) and "Hardy Tamarillo" (S. corymbiflorum) were used for crossing. These species' originated in southern Brazil and adjacent parts of Argentina and Paraguay (SOARES \& MENT 2006, BOHS 2007) and are grouped in the same taxonomic group - "Solanum diploconos clade". The attempts of crossing was made in the end of the XX century, but the partially successful crossings were only a part of taxonomic researchers (BOHS 1991). MEADOWS 2012 (www.naturalhub.com) tried to repeat the experiment of Bohs but was unsuccessful.

Both of the parent species have positive as well negative features from an agronomic point of view:

- Solanum corymbiflorum - "hardy tamarillo":

- it is deciduous and hardy to about (-8 to $-10 \mathrm{C}$ degree)

- starts blooming early in the year

- starts blooming early when grown from seeds

- has small seeds

- the stone cell granules are present in fruits

- fruits have mild taste but also unpleasant aftertaste,

- Solanum diploconos - "guava tamarillo" - the common name has been created on New Zealand during

the attempts to cultivating it - MEADOWS 2012 (www.naturalhub.com):

- it is evergreen and hardy to only about ( $-3 \mathrm{C}$ degree), but good grows in cool, frost free climate

- starts blooming late in the year

- starts blooming late when grown from seeds

- has small seeds

- the stone cell granules are absent in fruits

- it is pest and disease resistant (powdery mildew, whitefly)

- fruits are aromatic but very acid (BOHS 1989, PRINGLE \& MURRAY 1991a and our own insights).

There have been used crossing work methods described in breeding guides (BURBANK 1921, LAWRENCE 1957 and others). The experiment has been placed in USDA zone 7a. The plants have been grown in large pots, and they were kept outside in summers and during winters stored in a cool cellar or greenhouse (protected against stronger frosts). The flowers were protected against aleatory pollination by organza-nettle bags. They were hand pollinated. The pollination was made in summer months. Each crossing combination has been tested.

The aim of work was to connect good features of these two species by hybridisation and selection. In addition, there has been a hope to obtain new, valuable fruit varieties to commercial growing.

It was necessary wait eight years to Solanum diploconos to start blooming from seeds, so the whole research took almost 12 years, although the time taken to cross and select was strictly four years so far and is currently being continued.

The first experiment was to obtain a hybrid of $S$. corymbiflorum $\times S$. diploconos. The next step was to test backcrossing with both parents. Numerous hybrid individuals were obtained from these crossings with very variable appearances, especially within $\mathrm{BC} 1$ crossings due to the split of features. They were propagated easily by cuttings, so about $8-10$ individuals of each variety exist now and may start further dissemination.

The combinations of $\mathrm{BC} 1$ crossings with each of parents were obtained. The $\mathrm{F} 1$ hybrid $S$. corymbiflorum $\times$ S. diloconos and BC1 hybrid $(S$. corymbiflorum $\times$ diploconos $) \times$ corymbiforum have been created for the first time by BOHS (1991), but BC1 (S. corymbiflorum $\times$ diploconos) $\times S$. diploconos has been created as the first in the world by the authors.

About $60-70 \%$ pollinated flowers developed into fruits in the case crossing $S$. corymbiflorum $\times S$. diploconos. In November and December, the fruits ripened about 4 months later (finally were harvested over 20 hybrid fruits). The seeds were only partially viable, and their germination rate was low (about $5 \%$ ). About 9 seedlings for each 10 ones was chlorotic and died in young age. The seedlings started to bloom within a few months and next were created also BC1 hybrid (S. corymbiflorum $\times$ S. diploconos) $\times$ S. corymbiflorum .

Also backcrossing ( $S$. corymbiflorum $\times$ diploconos) $\times S$. diploconos was successful. Chlorotic seedlings were observed in the cases of both $\mathrm{BC} 1$ crosses but less frequent than in $\mathrm{F} 1$ combination. The chlorose in addition rarely deadly in these combinations. The seeds were also better developed and in a larger degree viable. The rate of viability of seeds in combination BC1 (S. corymbiflorum $\times$ S. diploconos) $\times$ S. corymbiflorum was about $20 \%$ and in the case BC1 (S. corymbiflorum $\times$ diploconos) $\times$ S. diploconos about $10 \%$. 
All cultivars can be easily propagated vegetatively by cuttings. Only vegetative propagation gives true cultivars. The following taxons were selected: 'Lynn', 'Pinczow Springs' and 'Iwona'. Descriptions of new cultivars (the most important features) are presented below:

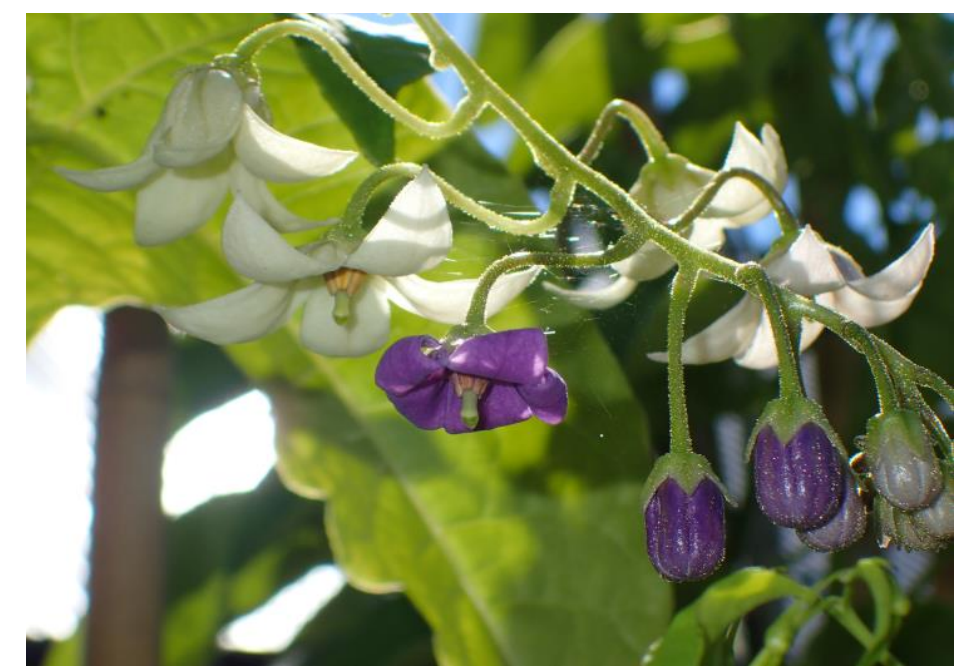

Figure 1. The flowers of Solanum 'Lynn'.

\section{Solanum corymbiflorum $\times$ S. diploconos (F1 hybrid)}

Deciduous (or half-evergreen if grown in warm climate), small tree about 1,5-3 $\mathrm{m}$ tall with regular, umbrella-like shape. Young trunk green with large pale-green spots near leaf petioles. Leaf-blades simple, dark-green, chartaceous to subcoriaceous. Trunk leaves simple, 3-lobed, large. Crown leaves simple, unlobed, smaller. Inflorescence unbranched or rarely forked, ca. 5-30-flowered. Flower buds tubularellipsoidal. Calyx chartaceous, the radius $5-12 \mathrm{~mm}$. Corolla lavender when young, fading to almost pure white with age (Figure 1), chartaceous to membranaceous, stellate, the radius $10-20 \mathrm{~mm}$. Anthers dirty lavender first, next pale yellow, elliptic. Connective lavender-yellow fading to dark-yellow. Stigma wide, concave, about 2-2,5 mm in diam., 2-3 mm exserted beyond stamens. Fruit ovate to almost roundish, ca.3$3,5 \times 2,5-3 \mathrm{~cm}$., dark-greenish with a few blurred, darker, longitudinal stripes - when falling down (Figure $2 A$ ), pale green-yellowish - when overripe. The flesh of ripe fruits orange-brown, overripe - bright orange yellow (Figure 2B). Seed usually only partially developed.

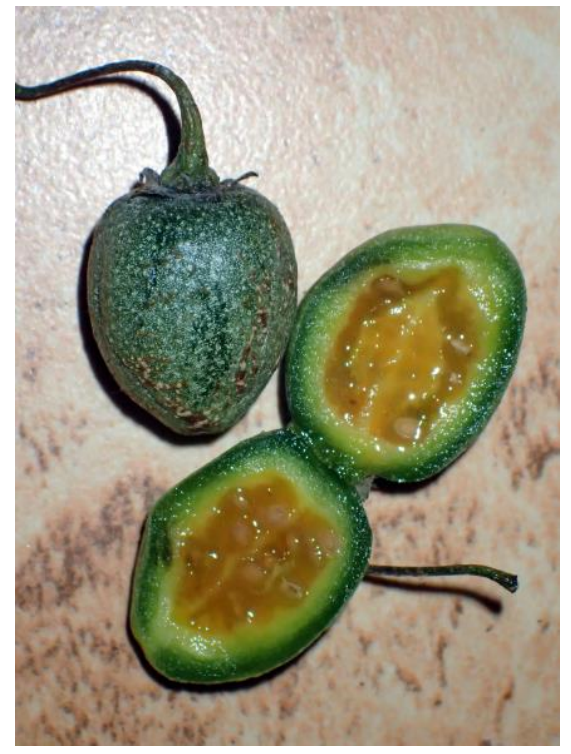

(A)

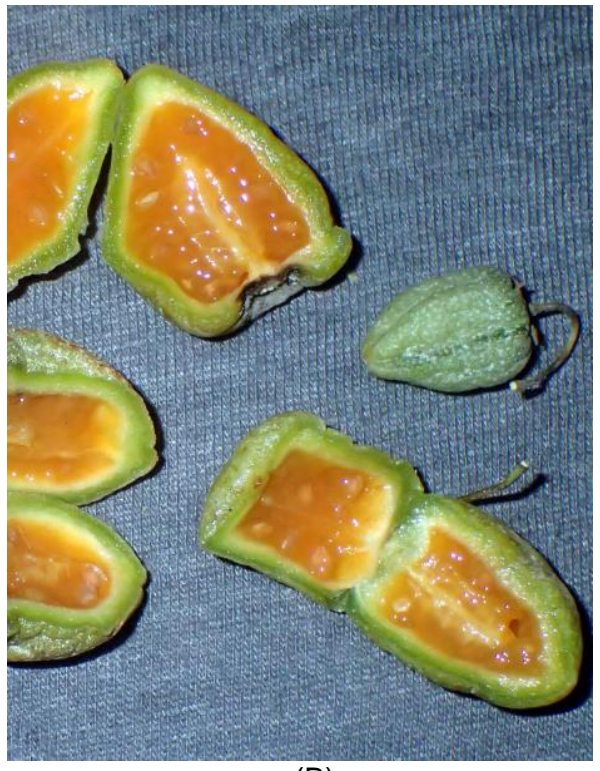

(B)

Eponym: the name of the cultivar is intended to honor the scientist, who started working with crossing $S$. corymbiflorum and $S$. diploconos and created this hybrid as the first one - prof. Lynn Bohs. Suggested common name: Tamarillo `Lynn`. Solanum `Lynn`. The cultivar standard: S Poland. Pińczów. In a greenhouse. September 2021, coll. Wojciech M. Szymański, Iwona Ziółkowska (KOR 55912).

Figure 2. The ripe fruits of Solanum 'Lynn' (A) and the overripe fruits of Solanum 'Lynn' (B). 


\section{Solanum 'Pinczow Springs' - (S. corymbiflorum $\times$ S. diploconos) $\times$ S. corymbiflorum (BC1 hybrid)}

Deciduous (or half-evergreen if grown in warm climate), shrub or small tree about 1,5-3 $\mathrm{m}$ tall with irregular shape. Leaf blades medium-green, simple, chartaceous to subcoriaceous. Trunk leaves simple, 3lobed. Crown leaves simple, unlobed, smaller. Inflorescence branched, ca. 30-50-flowered. Flower buds tubular-ellipsoidal. Calyx chartaceous, the radius $6-8 \mathrm{~mm}$. Corolla lavender-purple when young, fading to lavender-white with age (Figure 3A), chartaceous to membranaceous, stellate, the radius ca. 15-25 mm. Anther thecae yellow, oblong-elliptic. Connective yellow. Stigma narrow, concave, about $1 \mathrm{~mm}, 1,5-2 \mathrm{~mm}$ exserted beyond stamens. Fruit ovate, ca. $2-3 \mathrm{~cm} \times 1,5-2 \mathrm{~cm}$ in, shortly, shiny pubescent, pale-greenishwhite, with a few, darker, longitudinal stripes. The flesh of ripe fruits is pale creamy-white (Figure 3B). The seed are usually not fully developed

The reason we selected this cultivar was very valuable features in horticultural point of view. The fruit ripes very early (in our climate it can fruit even before first frosts in the end of September and in October). It also creates the heaviest crop. The wall of fruit is thick and firm by long time after harvest, so it can be stored by long time, even in room temperature. The flesh is pale creamy-white, not acid, but has distinct "tropical”, "bubble-gum like" taste. Fully ripe fruits of this variety have not the astringent aftertaste (which is characteristic to Solanum corymbiflorum).

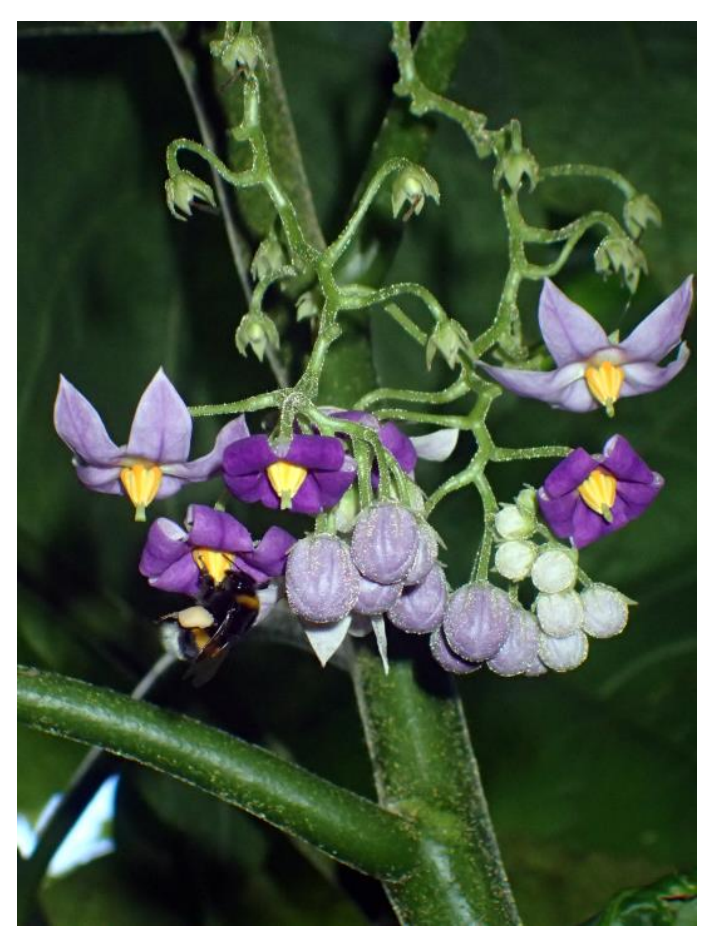

(A)

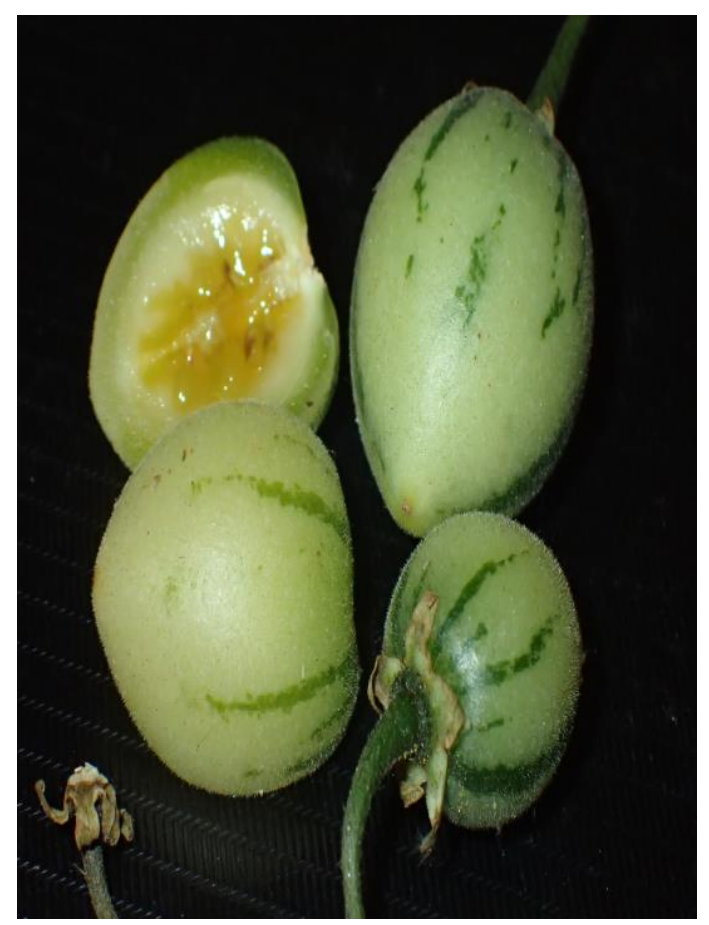

(B)

Eponym: The name refers to the planned health resort in town Pińczów (S Poland), when the experiment was conducted. Suggested common name: Tamarillo Pinczow Springs'. Solanum 'Pinczow Early'. The cultivar standard: S Poland. Pińczów. In a greenhouse. September 2021, coll. Wojciech M. Szymański, Iwona Ziółkowska (KOR 55913).

Figure 3. The Inflorescence of Solanum 'Pinczow Springs' (A) and the overripe fruits of Solanum 'Pinczow Springs' (B).

\section{Solanum Iwona' - (S. corymbiflorum $\times$ diploconos) $\times$ S. diploconos (BC1 hybrid)}

Deciduous (or half-evergreen if grown in warm climate), small tree about 0,5-2,5 $\mathrm{m}$ tall with regular shape. Leaf blades pale-green, simple, coriaceous. Trunk leaves simple, unlobed. Crown leaves simple, unlobed (Figure 4A). Inflorescence unbranched, ca. 5-20-flowered. Flower buds ovate, obtuse at apex. Calyx waxy, glabrous, the radius $8-10 \mathrm{~mm}$. Corolla first adaxially lavender, lavender-white adaxially, later changing color to pale aquamarine (Figure 4B). Shape of corolla first campanulate, next campanulatestellate (Figure $4 \mathrm{C}$ ). The radius of corolla $8-15 \mathrm{~mm}$. Anther thecae pale lavender first, next pale lavenderyellowish, elliptic. Connective lavender-yellowish fading to bright yellowish. Stigma concave with two apical glands, ca. $3 \mathrm{~mm}$ in diam, ca. $1 \mathrm{~mm}$ exserted beyond stamens. Fruit ovate to roundish-ovate, ca. 2-2,5 × 1,5 $\mathrm{cm}$, shortly pubescent, blurred fine, whitish papillary-spotted (Figure 4D). The color of overripe fruits, its flesh and taste are unknown because fruits have not ripped yet. 


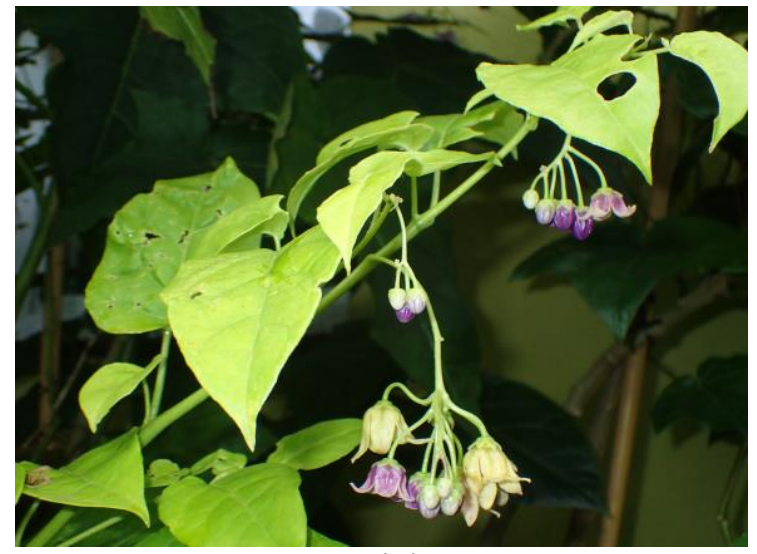

(A)

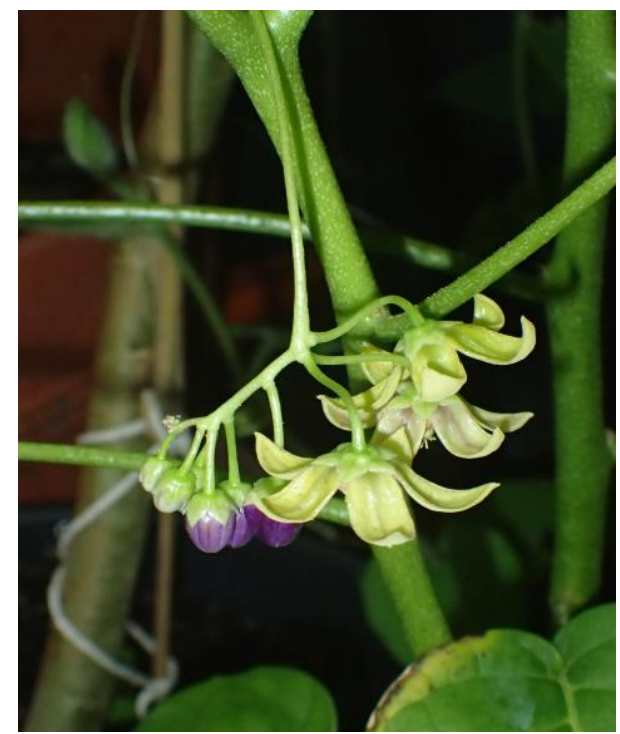

(C)

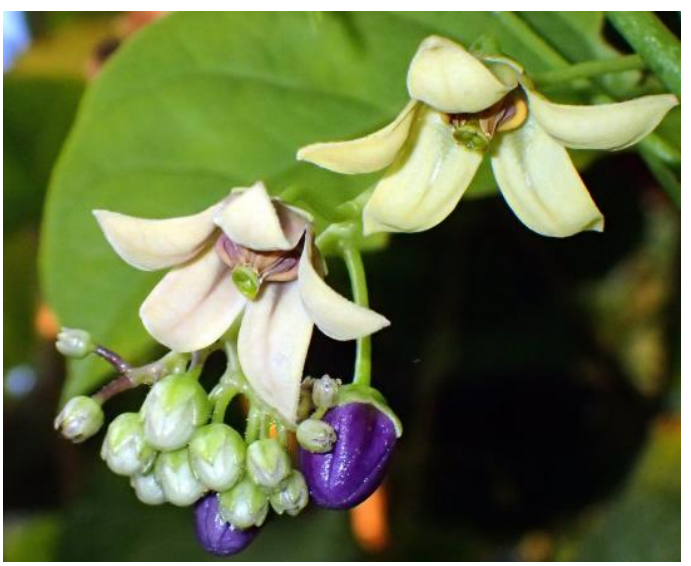

(B)

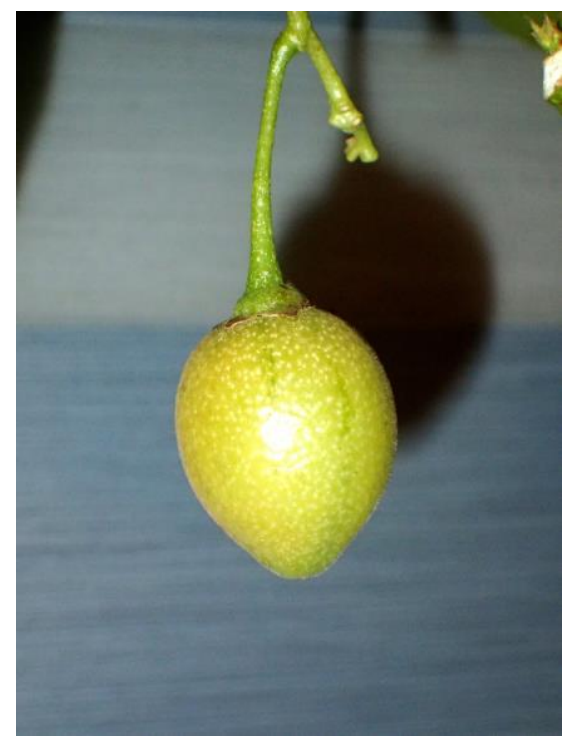

(D)

Figure 4. The pale green leaves of Solanum 'Iwona' (A), the flowers of Solanum 'wona' (B), The older flowers of Solanum 'Iwona' are campanulate-stellate shape (C), and the almost mature fruit of Solanum 'Iwona' (D).

This cultivar was selected due to its very valuable features in a horticultural viewpoint The above taxon ripes quite early, creates large crop, is deciduous and day-length neutral. The leaves of this cultivar are always unlobed, entire and pale green, but completely free of chlorose. The colour and organoleptic value of the fruits is unknown, due to the fruits still being unripe. Due to domination of $S$. diploconos genes there is suspected high organoleptic value of the fruits. This cultivar individuals bloom and fruit even when they are very small (about $0,5 \mathrm{~m}$ tall) and barely branched.

Eponym: Iwona - is the first name of one of the cultivar breeders and co-author of this paper.

Suggested common name: Tamarillo 'Iwona'

Solanum 'Iwona`. The cultivar standard: S Poland. Pińczów. In a greenhouse. September 2021, coll. Wojciech M. Szymański, Iwona Ziółkowska (KOR 55914)

In the botanic viewpoint the variety Solanum 'Lynn' stands out from others mainly by the color of their flowers (young- purple, older - almost pure white), 3-lobed trunk leaves and aquamarine color of overripe fruits with orange flesh with good taste. Solanum 'Pinczow Springs' individuals are very similar to $S$. corymbiflorum, but usually have 3-lobed trunk leaves, dirty purple-yellow anthers, larger flowers and inflorescences and has tasty fruits without an unpleasant aftertaste. Solanum 'Iwona' is similar to $S$. diploconos but differs mainly by the flowers' color (young- lavender, older - aquamarine), seasonal pale green, never lobed leaves (deciduous) and is day-length neutral.

The combinations of features within the chosen hybrids was noted and illustrated in Table 1. However, the hardiness remains untested. The research with crossing and selecting of Tamarillo species has been not finished yet. The results of further research and descriptions of the new cultivars will be presented soon. 
Table 1. The descriptions of the new cultivars' features and the parent species.

\begin{tabular}{|c|c|c|c|c|c|c|}
\hline No. & Feature & $\begin{array}{c}\text { Solanum } \\
\text { corymbiflorum } \\
\text { (parent) }\end{array}$ & $\begin{array}{c}\text { Solanum } \\
\text { diploconos } \\
\text { (parent) }\end{array}$ & Solanum 'Lynn' & $\begin{array}{c}\text { Solanum 'Pinczow } \\
\text { Springs' }\end{array}$ & Solanum Iwona' \\
\hline 1 & $\begin{array}{c}\text { time to blooming from } \\
\text { seeds }\end{array}$ & 1 year & 8 years & 0,5 year & 0,5 year & 1 year \\
\hline 2 & $\begin{array}{c}\text { start to blooming } \\
\left(50^{\circ} \mathrm{N} \text { latitude) }\right.\end{array}$ & May/June & August & July & June & June/July \\
\hline 3 & fertility & high & unknown & low & very high & high \\
\hline 4 & leafage & deciduous & $\begin{array}{c}\text { half- } \\
\text { evergreen }\end{array}$ & deciduous & deciduous & deciduous \\
\hline 5 & $\begin{array}{c}\text { start to fruiting } \\
\left(50^{\circ} \text { N latitude) }\right.\end{array}$ & November & December & October & September & November \\
\hline 6 & fruit size & $\begin{array}{c}\text { ca. } 2-2,5 \times \\
1,5-2 \mathrm{~cm}\end{array}$ & $\begin{array}{c}\text { ca. } 3,5-4 \times \\
3-3,5 \mathrm{~cm}\end{array}$ & $\begin{array}{c}\text { ca.3-3,5 } \times \\
2,5-3 \mathrm{~cm}\end{array}$ & $\begin{array}{c}\text { ca.2-3 } \times \\
1,5-2 \text { cm }\end{array}$ & $\begin{array}{c}\text { ca. } 2-2,5 \times \\
1,5-2 \text { cm }\end{array}$ \\
\hline 7 & $\begin{array}{c}\text { skin color } \\
\text { (overripe fruits) }\end{array}$ & $\begin{array}{c}\text { whitish-green, } \\
\text { darker striped }\end{array}$ & $\begin{array}{c}\text { yellow } \\
\text { pale-green, dark } \\
\text { striped }\end{array}$ & unknown yet \\
\hline 8 & flesh colour & pale-green & yellow & orange-yellow & pale-green & unknown yet \\
\hline 9 & fruit taste & $\begin{array}{c}\text { mild, unpleasant } \\
\text { aftertaste }\end{array}$ & $\begin{array}{c}\text { aromatic, } \\
\text { acid }\end{array}$ & $\begin{array}{c}\text { aromatic, } \\
\text { tasty }\end{array}$ & $\begin{array}{c}\text { mild, gently } \\
\text { aromatic }\end{array}$ & unknown yet \\
\hline 10 & stone-cell granules & present & absent & absent & absent & absent \\
\hline
\end{tabular}

\section{ACKNOWLEDGEMENTS}

We would like to thank to PhD. Denise F. Dostatny (National Centre for Plant Genetic Resources, Plant Breeding and Acclimatization Institute - NRI; Radzików, 05-870 Błonie, Poland) and Prof. dr. hab. Jerzy Zieliński (Institute of Dendrology, Polish Academy of Sciences, 62-035 Kórnik, Poland) for advices and help in creating this article.

\section{REFERENCES}

BOHS L. 1989. Ethnobotany of the Genus Cyphomandra (Solanaceae). Economic Botany 43: 143-163.

BOHS L. 1991. Crossing Studies in Cyphomandra (Solanaceae) and their systematic and evolutionary significance. American Journal of Botany 78: 1683-1693.

BOHS L. 1994. Cyphomandra (Solanaceae). In: Flora Neotropica. Band 63, New York Botanical Garden, New York, USA.

BOHS L. 1995. Transfer of Cyphomandra (Solanaceae) and Its Species to Solanum. Taxon 44: 583-587.

BOHS L. 2007. Phylogeny of the Cyphomandra Clade of the genus Solanum (Solanaceae) based on its sequence data. Taxon 56: 1012-1026

BURBANK L. 1921. Plant Breeding. Vol I. New York: Collier.

CHEN X et al. 2021a. Free and Glycosidic volatiles in tamarillo (Solanum betaceum Cav. Syn. Cyphomandra betacea Sendt.) juices prepared from three cultivars grown in New Zealand. Journal of Agricultural and Food Chemistry 69: 4518-4532.

CHEN X et al. 2021b. Elucidation of endogenous aroma compounds in tamarillo (Solanum betaceum) using a molecular sensory approach. Journal of Agricultural and Food Chemistry 69: 9362-9375.

FERNANDINO CM et al. 2021. Propriedades físico-químicas da polpa de tamarillo (Solanum betaceum) e sua aplicabilidade na elaboração de sorvetes. Brazilian Journal of Food Technology 24: e2020090.

HUME EP \& WINTERS HF. 1949. "The "Palo de Tomate" or tree tomato". Economic Botany 3: 140-142

LAWRENCE WJC. 1957. Practical Plant Breeding. G. Allen \& Unwin.

MEADOWS L. 2012. Growing rare Tamarillo relatives (Cyphomandra species) in New Zealan". www.naturalhub.com. Retrieved 6 December 2012.

PROHENS J \& NUEZ F. 2001. The tamarillo (Cyphomandra betacea): A review of a promising small fruit crop. Small Fruits Review 1: 43-68.

PRINGLE GJ \& MURRAY BG. 1991a. Interspecific hybridisation involving the tamarillo, Cyphomandra betacea (Cav.) Sendt. (Solanaceae). New Zealand Journal of Crop and Horticultural Science 19: 103-111

PRINGLE GJ \& MURRAY BG. 1991b. Reproductive biology of the tamarillo, Cyphomandra betacea (Cav.) Sendt. (Solanaceae), and some wild relatives. New Zealand Journal of Crop and Horticultural Science 19: 263-273.

REYES-GARCÍA V et al. 2021. Exploration of the potential bioactive molecules of tamarillo (Cyphomandra betacea): antioxidant properties and prebiotic index. Applied Sciences 11: 11322.

SOARES ELC \& MENTZ LA. 2006. As espécies de Solanum subgênero Bassovia Seção Pachyphylla (= Cyphomandra Mart. Ex Sendtn. - Solanaceae no Rio Grande do Sul), Brasil. Pesquisas, Botânica 57: 231-254.

WAN S \& ZHUB F. 2020. Tamarillo (Solanum betaceum): chemical composition, biological properties, and product innovation. Trends in Food Science \& Technology 95: 45-58. 